\title{
Phenolic constituents from twigs of Aleurites fordii and their biological activities
}

\author{
Kyoung Jin Park ${ }^{\ddagger 1}$, Won Se Suh ${ }^{\ddagger 1}$, Da Hye Yoon ${ }^{2}$, Chung Sub Kim ${ }^{1,3}$, Sun Yeou Kim² \\ and Kang Ro Lee*1,§
}

\author{
Full Research Paper \\ Address: \\ ${ }^{1}$ Natural Products Laboratory, School of Pharmacy, Sungkyunkwan \\ University, Suwon 16419, Republic of Korea, ${ }^{2}$ Laboratory of \\ Pharmacognosy, College of Pharmacy, Gachon University, Incheon, \\ 21936, Republic of Korea and ${ }^{3}$ Department of Biopharmaceutical \\ Convergence, Sungkyunkwan University, Suwon 16419, Republic of \\ Korea \\ Email: \\ Kang Ro Lee* - krlee@skku.edu \\ * Corresponding author $\ddagger$ Equal contributors \\ $\S$ Phone +82-31-290-7710; fax +82-31-290-7730 \\ Keywords: \\ Aleurites fordii; antineuroinflammation; Euphorbiaceae; neolignan \\ glycoside; neuroprotective activity; phenolic compound \\ Beilstein J. Org. Chem. 2021, 17, 2329-2339. \\ https://doi.org/10.3762/bjoc.17.151 \\ Received: 13 April 2021 \\ Accepted: 24 August 2021 \\ Published: 07 September 2021 \\ Associate Editor: S. Bräse \\ (C) 2021 Park et al.; licensee Beilstein-Institut. \\ License and terms: see end of document.
}

Open Access

\section{Abstract}

Three new neolignan glycosides (1-3), a new phenolic glycoside (15), and a new cyanoglycoside (16) were isolated and characterized from the twigs of Aleurites fordii together with 14 known analogues (4-14 and 17-19). The structural elucidation of the new compounds was performed through the analysis of their NMR, HRMS, and ECD spectra and by chemical methods. All isolated compounds were tested for their antineuroinflammatory and neuroprotective activities.

\section{Introduction}

Aleurites fordii Hemsl. (= Vernicia fordii Hemsl., Euphorbiaceae), known as tung oil tree, is widely distributed throughout Northeast Asia [1]. The fruits, leaves, and roots of this plant have been used as a Korean traditional medicine for treating sore throat, respiratory illness, constipation, and dieresis [2,3]. Phytochemical investigations of A. fordii reported coumarins, diterpenoid esters, triterpenoids, and tannins [4-7]. Some phorbol diterpenoids isolated from A. fordii have shown Epstein-Barr virus activation effects and an enhancement of HTLV-I-induced colony formation of lymphocytes [8].
As an ongoing search for bioactive secondary metabolites from Korean medicinal sources, we investigated the methanolic extract of the twigs of $A$. fordii which resulted in the isolation and characterization of 14 lignan derivatives including three new neolignan glycosides (1-3), four phenolic glycosides including a new compound (15), and a new cyanoglycoside (16) from the organic extracts. The structures of the new compounds were established by NMR analysis $\left({ }^{1} \mathrm{H}\right.$ and ${ }^{13} \mathrm{C} \mathrm{NMR}$, COSY, HSQC, HMBC, and NOESY), HRMS, and chemical methods. The isolated compounds 1-19 were evaluated for their 
antineuroinflammatory and neuroprotective activities. In this paper, we report the isolation and structural elucidation of these phytochemicals and their biological activity.

\section{Results and Discussion}

The $\mathrm{MeOH}$ extract of $A$. fordii twigs was subjected to liquid-liquid solvent partitioning to yield $n$-hexane, $\mathrm{CHCl}_{3}$, EtOAc, and $n-\mathrm{BuOH}$-soluble fractions. Repeated column chro- matographic purification of the $\mathrm{CHCl}_{3}$, EtOAc, and $n-\mathrm{BuOH}$ soluble fractions afforded three new neolignan glycosides (1-3), a new phenolic glycoside (15), a new cyanoglucoside (16), and 14 known compounds (4-14 and 17-19) (Figure 1).

Compound $\mathbf{1}$ was obtained as a colorless gum. The molecular formula was determined to be $\mathrm{C}_{25} \mathrm{H}_{32} \mathrm{O}_{11}$ from the $[\mathrm{M}+\mathrm{Na}]^{+}$ molecular ion peak in the positive mode HRFABMS. The<smiles>CCOC(=O)OC[C]Cc1cc(O)c2c(c1)[C@H](CO)[C@H](c1ccc(O)c(OC)c1)O2</smiles>

1<smiles>[R10]C#[13C]Oc1ccc([C@@H]2Oc3c(OC)cc(CCCO)cc3[C@@H]2CO)cc1OC</smiles>

2<smiles>[R2]OCCCc1ccc(O[C@H](CO)[C@H](O[Z2])c2ccc(O)c(OC)c2)c(OC)c1</smiles>

$$
3 \mathrm{R}=\mathrm{H}
$$

$8 \mathrm{R}=\mathrm{OCH}_{3}$

$$
\begin{array}{ccc}
4 & \beta \text {-D-Glc } & \mathrm{OCH}_{3} \\
5 & \alpha \text {-L-Rha } & \mathrm{OCH}_{3} \\
\mathbf{6} & \alpha \text {-L-Rha } & \mathrm{OH} \\
7 & \mathrm{~A} & \mathrm{OCH}_{3}
\end{array}
$$

$97 R, 8 R, \mathrm{R}^{1}=\beta$-D-Glc, $\mathrm{R}^{2}=\mathrm{H}$

$107 R, 8 R, \mathrm{R}^{1}=\mathrm{H}, \mathrm{R}^{2}=\mathrm{H}$

$117 S, 8 S, R^{1}=H, R^{2}=H$

$127 R, 8 S, R^{1}=\beta$-D-Glc, $R^{2}=H$

$137 S, 8 R, R^{1}=H, R^{2}=\beta-D-G l c$<smiles>C/C=C\C=C/C(C)C(CO)Oc1c(O)cc([C@@H]2Oc3c(O)cc(/C=C/C=O)cc3[C@@H]2CO)cc1OC</smiles>

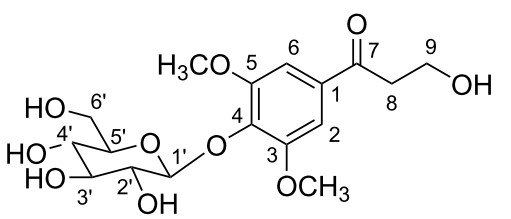
$\mathrm{H}_{3} \mathrm{CO}$<smiles></smiles>

16<smiles>[CH][CH]C(CO)CO</smiles><smiles>[Z6][C]1O[C@H]([14CH2]O)[C@@H](O)[C@H](O)[C@H]1O</smiles>
$\alpha-\mathrm{L}-\mathrm{Rh} a=$
17<smiles>[CH2][C@H]1O[C@H](C)[C@@H](O)[C@H](O)[C@H]1O</smiles> 
${ }^{1} \mathrm{H}$ NMR data (Table 1 ) of compound $\mathbf{1}$ displayed characteristic resonances for a 1,3,4-trisubstituted benzene ring $\left[\delta_{\mathrm{H}} 7.00(\mathrm{~d}\right.$, $J=1.9 \mathrm{~Hz}, \mathrm{H}-2), 6.87$ (dd, $J=8.1,1.9 \mathrm{~Hz}, \mathrm{H}-6)$, and 6.78 (d, $J=8.1 \mathrm{~Hz}, \mathrm{H}-5)]$, a 1,3,4,5-tetrasubsituted benzene ring [ $\delta_{\mathrm{H}} 6.62$ (brs, H-2') and 6.65 (brs, H- $\left.\left.6^{\prime}\right)\right]$, an oxygenated methine $\left[\delta_{\mathrm{H}} 5.51(\mathrm{~d}, J=6.1 \mathrm{~Hz}, \mathrm{H}-7)\right]$, an anomeric proton of a sugar $\left[\delta_{\mathrm{H}} 4.27\left(\mathrm{~d}, J=7.8 \mathrm{~Hz}, \mathrm{H}-1^{\prime \prime}\right)\right]$, and a methoxy group $\left[\delta_{\mathrm{H}} 3.84\left(\mathrm{~s}, 3-\mathrm{OCH}_{3}\right)\right]$. The ${ }^{13} \mathrm{C}$ NMR data (Table 1) showed 25 peaks including 12 aromatic carbons $\left[\delta_{\mathrm{C}} 147.6(\mathrm{C}-3), 145.9\right.$ (C-4), $145.1\left(\mathrm{C}-4^{\prime}\right), 140.4\left(\mathrm{C}-3^{\prime}\right), 135.2\left(\mathrm{C}-1^{\prime}\right), 133.7$ (C-1), $128.3\left(\mathrm{C}-5^{\prime}\right), 118.2$ (C-6), 115.8 (C-2'), $115.3\left(\mathrm{C}^{\prime} 6^{\prime}\right), 114.6$ $(\mathrm{C}-5)$, and $109.1(\mathrm{C}-2)]$ and six glucose carbons $\left[\delta_{\mathrm{C}} 103.0\right.$ $\left(\mathrm{C}-1^{\prime \prime}\right), 76.7$ (C-3"), $76.5\left(\mathrm{C}-5^{\prime \prime}\right), 73.7\left(\mathrm{C}-2^{\prime \prime}\right), 70.2$ (C-4"), and $\left.61.3\left(\mathrm{C}-6^{\prime \prime}\right)\right]$. The spectroscopic data of compound 1 suggested that it is a typical dihydrobenzofuran neolignan glycoside [9-11]. The data for compound 1 were similar to those of glochidioboside isolated from Glochidion obovatum [12], except for the presence of a hydroxy group instead of the methoxy group at C-3' in $\mathbf{1}$. The two-dimensional structure of $\mathbf{1}$ was elucidated via analysis of COSY, HSQC, and HMBC spectroscopic data (Figure 2). The locations of the glucose unit and the methoxy group were confirmed from the observed HMBC correlations of $\mathrm{H}-1^{\prime \prime} / \mathrm{C}-9^{\prime}$ and $3-\mathrm{OCH}_{3} / \mathrm{C}-3$, respectively (Figure 2). Acid hydrolysis of $\mathbf{1}$ was conducted to analyze the aglycone and sugar moiety. The structure of the aglycone (1a) was confirmed as demethyldihydrodehydrodiconiferyl alcohol based on the comparison of ${ }^{1} \mathrm{H}$ NMR and MS data [13]. The relatively large coupling constant of the anomeric proton

Table 1: ${ }^{1} \mathrm{H}$ and ${ }^{13} \mathrm{C}$ NMR spectroscopic data of compounds $1-3$ in $\mathrm{CD}_{3} \mathrm{OD}$.

\begin{tabular}{|c|c|c|c|c|c|c|}
\hline \multirow{2}{*}{ Pos. } & \multicolumn{2}{|r|}{$1^{a}$} & \multicolumn{2}{|r|}{$2^{b}$} & \multicolumn{2}{|r|}{$3^{a}$} \\
\hline & $\delta_{C}$ & $\delta_{H}(J$ in $H z)$ & $\delta_{C}$ & $\delta_{H}(J$ in $H z)$ & $\delta_{C}$ & $\delta_{H}(J$ in $H z)$ \\
\hline 1 & 133.7 & & 134.3 & & 131.9 & \\
\hline 2 & 109.1 & $7.00, d(1.9)$ & 112.3 & $7.06, \mathrm{~d}(2.0)$ & 112.2 & $6.58, d(2.3)$ \\
\hline 3 & 147.6 & & 152 & & 146.9 & \\
\hline 4 & 145.9 & & 146.6 & & 143.9 & \\
\hline 5 & 114.6 & $6.78, d(8.1)$ & 119.4 & $7.12, \mathrm{~d}(8.0)$ & 114.2 & $6.57 \mathrm{~d}(8.0)$ \\
\hline 6 & 118.2 & $6.87, \mathrm{dd}(8.1,1.9)$ & 120.1 & $6.92, \mathrm{dd}(8.0,2.0)$ & 121.2 & $6.49 \mathrm{dd}(8.0,2.3)$ \\
\hline \multirow[t]{2}{*}{7} & 87.3 & $5.51, \mathrm{~d}(6.1)$ & 88.3 & $5.85, \mathrm{~d}(8.8)$ & 37.8 & $2.99 \mathrm{dd}(13.8,5.5)$ \\
\hline & & & & & & $2.72 \mathrm{dd}(13.8,9.6)$ \\
\hline 8 & 54.3 & 3.47, dd $(12.6,6.1)$ & 50.2 & $3.69, \mathrm{~m}$ & 41.3 & $3.98, \mathrm{~m}$ \\
\hline \multirow[t]{2}{*}{9} & 63.7 & 3.85, overlap & 63.6 & $3.31, \mathrm{~m}$ & 65.6 & $3.77 \mathrm{dd}(10.7,6.2)$ \\
\hline & & $3.77, \mathrm{dd}(11.0,7.5)$ & & & & $3.68 \mathrm{dd}(10.7,7.3)$ \\
\hline $1^{\prime}$ & 135.2 & & 137.1 & & 138.9 & \\
\hline $2^{\prime}$ & 115.8 & 6.62 , br s & 114.3 & 6.76 , br s & 110.3 & $6.73, \mathrm{~s}$ \\
\hline $3^{\prime}$ & 140.4 & & 145.3 & & 151.6 & \\
\hline $4^{\prime}$ & 145.1 & & 147.5 & & 142.2 & \\
\hline $5^{\prime}$ & 128.3 & & 131.9 & & 137.1 & \\
\hline $6^{\prime}$ & 115.3 & 6.65, br s & 119.2 & $6.85, \mathrm{br} s$ & 118.9 & $6.73, \mathrm{~s}$ \\
\hline 7 & 31.2 & $2.63, \mathrm{~m}$ & 33.1 & $2.65, \mathrm{t}(7.5)$ & 31.7 & $2.66, \mathrm{~m}$ \\
\hline $8^{\prime}$ & 31.5 & $1.90, \mathrm{dt}(13.5,6.6)$ & 35.9 & $1.85, \mathrm{~m}$ & 34.1 & 1.84, tt $(13.0,6.5)$ \\
\hline \multirow[t]{2}{*}{$9^{\prime}$} & 68.5 & $3.93, \mathrm{~m}$ & 62.4 & $3.59, \mathrm{t}(6.5)$ & 60.8 & $3.59, \mathrm{td}(6.5,1.9)$ \\
\hline & & $3.56, \mathrm{~m}$ & & & & \\
\hline $1^{\prime \prime}$ & 103.0 & $4.27 \mathrm{~d}(7.8)$ & 101.6 & $5.37, \mathrm{~d}(1.8)$ & 104.2 & $4.63 \mathrm{~d}(7.6)$ \\
\hline $2^{\prime \prime}$ & 73.7 & 3.22 dd $(9.1,7.8)$ & 72.2 & $4.08, \mathrm{~m}$ & 74.5 & $3.47, \mathrm{~m}$ \\
\hline $3^{\prime \prime}$ & 76.7 & $3.37 \mathrm{dd}(10.8,9.1)$ & 72.4 & $3.89, \mathrm{~m}$ & 76.4 & $3.42, \mathrm{~m}$ \\
\hline $4^{\prime \prime}$ & 70.2 & $3.30, \mathrm{~m}$ & 74 & $3.47, \mathrm{~m}$ & 69.8 & $3.39, \mathrm{~m}$ \\
\hline $5^{\prime \prime}$ & 76.5 & 3.27 ddd $(9.6,5.6,2.2)$ & 71 & $3.83, \mathrm{~m}$ & 76.6 & 3.14 ddd $(9.2,5.2,2.3)$ \\
\hline \multirow[t]{2}{*}{$6^{\prime \prime}$} & 61.3 & $3.88 \mathrm{dd}(12.0,2.2)$ & 18.1 & $1.24, \mathrm{~d}(6.2)$ & 61.0 & $3.80 \mathrm{dd}(11.0,8.7)$ \\
\hline & & $3.69 \mathrm{dd}(12.0,5.6)$ & & & & 3.70 , overlap \\
\hline $3-\mathrm{OCH}_{3}$ & 54.9 & $3.84, \mathrm{~s}$ & 56.9 & $3.89, \mathrm{~s}$ & 54.8 & $3.71, \mathrm{~s}$ \\
\hline $3^{\prime}-\mathrm{OCH}_{3}$ & & & 56.6 & $3.83, \mathrm{~s}$ & 54.9 & $3.82, \mathrm{~s}$ \\
\hline
\end{tabular}

aMeasured at $700\left(\delta_{H}\right)$ and $175\left(\delta_{C}\right) \mathrm{MHz}$. b Measured at $500\left(\delta_{\mathrm{H}}\right)$ and $125\left(\delta_{\mathrm{C}}\right) \mathrm{MHz}$. 


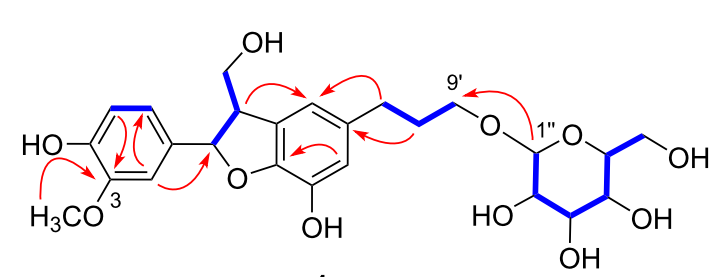

1

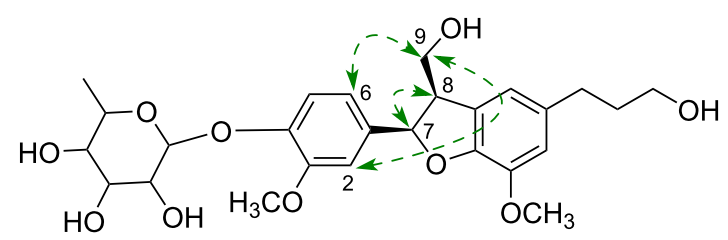

2

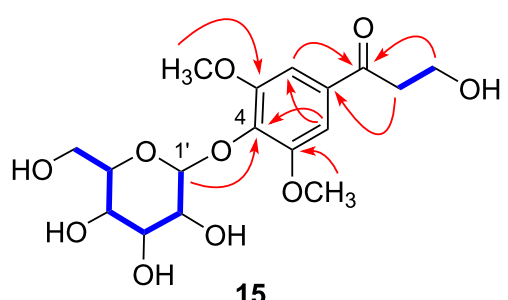

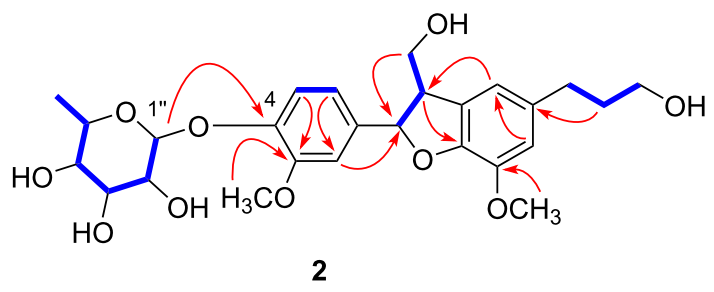

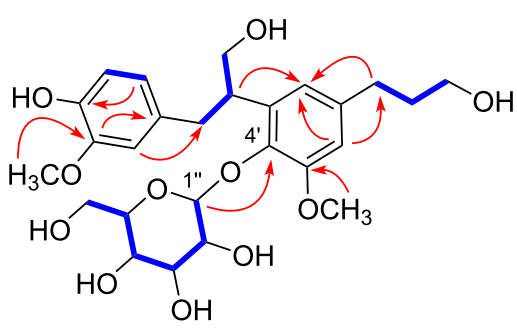

$\longrightarrow$ COSY
$\rightarrow$ HMBC
$\leftarrow$ NOESY

3

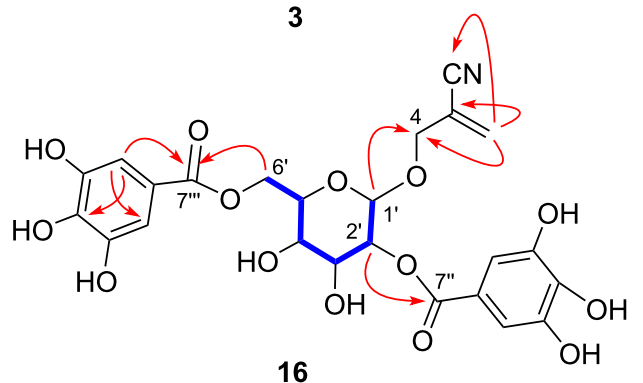

Figure 2: Key COSY and HMBC correlations of compounds 1-3, 15, and 16 and key NOESY correlation of 2.

$(7.8 \mathrm{~Hz})$ confirmed that the glucose is combined as $\beta$-form [14]. D-Glucose was identified by co-TLC with a standard sample $\left.\left[\mathrm{CHCl}_{3} / \mathrm{MeOH} / \mathrm{H}_{2} \mathrm{O} 2: 1: 0.1, R_{\mathrm{f}}=0.3\right)\right]$ and GC-MS analysis [15]. The relative configuration at C-7/C-8 of $\mathbf{1}$ was established as trans through the relatively small coupling constant $(6.1 \mathrm{~Hz})$ $[10,16]$. The analysis of the ECD spectrum of 1 determined the absolute configuration of 1 to be $7 S$ and $8 R$ (positive Cotton effects (CEs) at 292 and $248 \mathrm{~nm}$, and a negative CE at $221 \mathrm{~nm}$; see Supporting Information File 1, Figure S7) [10]. Thus, the structure of compound 1 was elucidated as $(7 S, 8 R)-3^{\prime}-$ demethyldihydrodehydrodiconiferyl alcohol 9'-O- $\beta$-D-glucopyranoside, and was named as aleuritiside $\mathrm{A}$.

The molecular formula of compound $\mathbf{2}$, isolated as a colorless gum, was confirmed to be $\mathrm{C}_{26} \mathrm{H}_{34} \mathrm{O}_{10}$ from the positive ion mode HRESIMS data. The ${ }^{1} \mathrm{H}$ and ${ }^{13} \mathrm{C}$ NMR spectra of 2 were very close to that of icariside $\mathrm{E}_{4}$ (5) [17] with significant differences in the chemical shifts of C-1, C-8, C-9, C-5', and C-6' [2: $\delta_{\mathrm{C}} 134.3,50.2,63.6,131.9$, and 119.2; 5: $\delta_{\mathrm{C}} 138.9,55.7,65.1$, 129.7, and 118.0, respectively], indicating that compound 2 could be a stereoisomer of 5 at C-7 and C-8. The inspection of the COSY, HSQC, and HMBC spectra confirmed the planar structure of 2. The HMBC correlation of $\mathrm{H}-1$ " to C-4 indicated that the rhamnose unit was linked to the oxygen at C-4 and the characteristic $J$ value of the anomeric proton $(1.5 \mathrm{~Hz})$ confirmed the rhamnose as $\alpha$-form (Figure 2) [10]. Acid hydrolysis of compound 2 afforded the aglycone, dihydrodehydrodiconiferyl alcohol (2a) [18], and L-rhamnose $\left([\alpha]_{\mathrm{D}}{ }^{25}+9.0\right)$, which was identified in an identical manner to that of compound $\mathbf{1}$. The relatively large coupling constant $(8.8 \mathrm{~Hz})$ between H-7 and H-8 in $\mathbf{2}$, as opposed to the relatively small coupling constant $(6.1 \mathrm{~Hz})$ between $\mathrm{H}-7$ and $\mathrm{H}-8$ in 1, verified that $\mathrm{H}-7$ and $\mathrm{H}-8$ are cis-oriented $[10,16]$, which was supported by the NOESY correlations of $\mathrm{H}-7 / \mathrm{H}-8, \mathrm{H}-2 / \mathrm{H}-9$, and $\mathrm{H}-6 / \mathrm{H}-9$ (Figure 2). The ECD spectrum of $\mathbf{2}$ showed negative CEs at $276 \mathrm{~nm}$ and $229 \mathrm{~nm}$ and a positive $\mathrm{CE}$ at $248 \mathrm{~nm}$, indicating the absolute configuration of $\mathrm{C}-7$ and $\mathrm{C}-8$ as $R$ (Figure $\mathrm{S} 15$ in Supporting Information File 1) [19]. Therefore, the structure of compound 2 was determined to be $(7 R, 8 R)$-dihydrodehydrodiconiferyl alcohol 4- $O-\alpha$-L-rhamnopyranoside and was named as aleuritiside B.

Compound 3 was obtained as a colorless gum after purification with a molecular formula of $\mathrm{C}_{26} \mathrm{H}_{36} \mathrm{O}_{11}$ as deduced from the positive molecular ion peak $[\mathrm{M}+\mathrm{Na}]^{+}$at $m / z 547.2155$ (calcd for $\left.\mathrm{C}_{26} \mathrm{H}_{36} \mathrm{O}_{11} \mathrm{Na}, 547.2155\right)$ in the HRESIMS. Analysis of the ${ }^{1} \mathrm{H}$ and ${ }^{13} \mathrm{C}$ NMR data (Table 1) showed a 1,3,4-trisubstituted benzene ring $\left[\delta_{\mathrm{H}} 6.58(\mathrm{~d}, J=2.3 \mathrm{~Hz}, \mathrm{H}-2), 6.57(\mathrm{~d}, J=8.0 \mathrm{~Hz}\right.$, 
H-5), and 6.49 (dd, $J=8.0,2.3 \mathrm{~Hz}, \mathrm{H}-6)$; $\delta_{\mathrm{C}} 146.9$ (C-3), 143.9 (C-4), 131.9 (C-1), 121.2 (C-6), 114.2 (C-5), and 112.2 (C-2)], a 1,3,4,5-tetrasubstituted benzene ring $\left[\delta_{\mathrm{H}} 6.73\left(\mathrm{~s}, \mathrm{H}-2^{\prime}, 6^{\prime}\right) ; \delta_{\mathrm{C}}\right.$ 151.6 (C-3'), 142.2 (C-4'), 138.9 (C-1'), 137.1 (C-5'), 118.9 $\left(\mathrm{C}-6^{\prime}\right)$, and $\left.110.3\left(\mathrm{C}-2^{\prime}\right)\right]$, a glucopyranose unit $\left[\delta_{\mathrm{H}} 4.63(\mathrm{~d}, J=\right.$ $\left.7.6 \mathrm{~Hz}, \mathrm{H}-1^{\prime \prime}\right)$; $\delta_{\mathrm{C}} 104.2\left(\mathrm{C}-1^{\prime \prime}\right), 76.6\left(\mathrm{C}-5^{\prime \prime}\right), 76.4\left(\mathrm{C}-3^{\prime \prime}\right), 74.5$ $\left(\mathrm{C}-2^{\prime \prime}\right), 69.8\left(\mathrm{C}-4^{\prime \prime}\right)$, and $\left.61.0\left(\mathrm{C}-6^{\prime \prime}\right)\right]$, and two methoxy groups $\left[\delta_{\mathrm{H}} 3.82\left(\mathrm{~s}, 3^{\prime}-\mathrm{OCH}_{3}\right)\right.$ and $3.71\left(\mathrm{~s}, 3-\mathrm{OCH}_{3}\right) ; \delta_{\mathrm{C}} 54.9(\mathrm{~s}$, $\left.3^{\prime}-\mathrm{OCH}_{3}\right)$ and $\left.54.8\left(\mathrm{~s}, 3-\mathrm{OCH}_{3}\right)\right]$. The spectroscopic data resembled closely to those of icariside $\mathrm{E}_{3}$, isolated from Epimedium grandiflorum var. thunbergianum [20], indicating that compound $\mathbf{3}$ may have the identical planar structure to icariside $\mathrm{E}_{3}$, which was reported without assignment of the absolute configuration. The planar structure of $\mathbf{3}$ was further confirmed by analysis of 2D NMR data, including COSY, HSQC, and HMBC (Figure 2). The determination of the stereochemistry for the sugar unit of $\mathbf{3}$ was conducted following the same method as for compound 2 . The structure of the aglycone $\mathbf{3 a}$ obtained by acid hydrolysis of $\mathbf{3}$ was confirmed based on ${ }^{1} \mathrm{H}$ NMR and MS data [20]. The absolute configuration of $\mathbf{3 a}$ was established as $8 S$ (a negative $\mathrm{CE}$ at $273 \mathrm{~nm}$ ) based on the comparison of its ECD spectrum with the reported data [21]. Thus, the structure of compound 3 was determined as $8 S$-tetrahydrodehydrodiconiferyl alcohol 4- $O$ - $\alpha$-L-rhamnopyranoside and was named aleuritiside $\mathrm{C}$.

Compound 15 was obtained as a yellow gum. The $[\mathrm{M}+\mathrm{Na}]^{+}$ ion peak at $\mathrm{m} / \mathrm{z} 411.1260$ (calcd for 411.1267) in the HRESIMS corresponded to the molecular formula $\mathrm{C}_{17} \mathrm{H}_{24} \mathrm{O}_{10}$. The IR spectrum exhibited signals at $3321 \mathrm{~cm}^{-1}$ and $1675 \mathrm{~cm}^{-1}$ suggesting the presence of hydroxy and carbonyl groups, respectively. The ${ }^{1} \mathrm{H}$ NMR spectrum of compound 15 (Table 2)

Table 2: ${ }^{1} \mathrm{H}$ and ${ }^{13} \mathrm{C}$ NMR spectral data of 15 and 16 in $\mathrm{CD}_{3} \mathrm{OD}$.

$15^{a}$

\begin{tabular}{|c|c|c|c|c|}
\hline & $\delta_{C}$ & $\delta_{\mathrm{H}}(\mathrm{J}$ in $\mathrm{Hz})$ & $\delta_{C}$ & $\delta_{\mathrm{H}}(J$ in $\mathrm{Hz})$ \\
\hline 1 & 134.6 & & 121.3 & \\
\hline 2 & 107.5 & $7.23, \mathrm{~s}$ & 118.2 & \\
\hline \multirow[t]{2}{*}{3} & 154.4 & & 133.2 & 5.97, br s \\
\hline & & & & 5.95, br s \\
\hline \multirow[t]{2}{*}{4} & 140.7 & & 69.3 & 4.34, dd $(13.7,1.5)$ \\
\hline & & & & 4.22, dd $(13.7,1.5)$ \\
\hline 5 & 154.4 & & & \\
\hline 6 & 107.5 & $7.23, \mathrm{~s}$ & & \\
\hline 7 & 200.0 & & & \\
\hline 8 & 42.1 & $3.23, \mathrm{t}(6.0)$ & & \\
\hline 9 & 58.8 & $3.96, \mathrm{t}(6.0)$ & & \\
\hline $1^{\prime}$ & 104.6 & $5.00, \mathrm{~d}(7.7)$ & 102.1 & $4.70, d(8.0)$ \\
\hline $2^{\prime}$ & 75.8 & $3.51, \mathrm{~m}$ & 75.2 & $4.99, \mathrm{dd}(9.5,8.0)$ \\
\hline $3^{\prime}$ & 78.6 & $3.23, \mathrm{~m}$ & 76.0 & $3.70, \mathrm{~m}$ \\
\hline $4^{\prime}$ & 71.5 & $3.42, \mathrm{~m}$ & 71.8 & $3.57, \mathrm{~m}$ \\
\hline $5^{\prime}$ & 78.1 & $3.44, \mathrm{~m}$ & 76.2 & 3.67, m \\
\hline \multirow[t]{2}{*}{$6^{\prime}$} & 62.7 & $3.76, \mathrm{dd}(12.0,2.0)$ & 64.5 & 4.57, dd $(12.0,2.0)$ \\
\hline & & 3.66, dd $(12.0,5.0)$ & & 4.46, dd $(12.0,5.0)$ \\
\hline $1^{\prime \prime}$ & & & 121.4 & \\
\hline $2^{\prime \prime}, 6^{\prime \prime}$ & & & 110.6 & $7.10 \mathrm{~s}$ \\
\hline $3^{\prime \prime}, 5^{\prime \prime}$ & & & 146.6 & \\
\hline $4^{\prime \prime}$ & & & 140.1 & \\
\hline $7^{\prime \prime}$ & & & 167.7 & \\
\hline $1^{\prime \prime \prime}$ & & & 121.4 & \\
\hline $2^{\prime \prime \prime}, 6^{\prime \prime \prime}$ & & & 110.3 & $7.11 \mathrm{~s}$ \\
\hline $3^{\prime \prime \prime}, 5^{\prime \prime \prime}$ & & & 146.7 & \\
\hline $4^{\prime \prime \prime}$ & & & 140.1 & \\
\hline $7^{\prime \prime \prime}$ & & & 168.4 & \\
\hline $3,5-\mathrm{OCH}_{3}$ & 57.3 & $3.81, \mathrm{~s}$ & & \\
\hline
\end{tabular}

aMeasured at $700\left(\delta_{H}\right)$ and $175\left(\delta_{C}\right)$ MHz. b Measured at $500\left(\delta_{H}\right)$ and $125\left(\delta_{C}\right)$ MHz. 
exhibited signals for a 1,3,4,5-tetrasubstituted aromatic ring $\left[\delta_{\mathrm{H}}\right.$ 7.23 (s, 2H, H-2 and H-6)], two methoxy groups $\left[\delta_{\mathrm{H}} 3.81\right.$ (s, $\left.\left.6 \mathrm{H}, 3,5-\mathrm{OCH}_{3}\right)\right]$, an anomeric proton $\left[\delta_{\mathrm{H}} 5.00(\mathrm{~d}, J=7.7 \mathrm{~Hz}\right.$, $\left.1 \mathrm{H}, \mathrm{H}-1^{\prime}\right)$ ], and two methylenes $\left[\delta_{\mathrm{H}} 3.23(\mathrm{t}, J=6.0 \mathrm{~Hz}, 2 \mathrm{H}\right.$, $\mathrm{H}-8)$ and $3.96(\mathrm{t}, J=6.0 \mathrm{~Hz}, 2 \mathrm{H}, \mathrm{H}-9)]$. The ${ }^{13} \mathrm{C}$ NMR spectrum of compound 15 (Table 2) revealed 14 peaks for 17 carbons including a ketone carbon $\left(\delta_{C} 200.0\right)$, a 1,3,4,5-tetrasubstituted aromatic ring $\left[\delta_{C} 154.4(\times 2), 140.7,134.6\right.$, and $107.5(\times 2)]$, two methoxy groups $[57.3(\times 2)]$, and a glucose unit $\left(\delta_{C} 104.6,78.6,78.1,75.8,71.5\right.$, and 62.7$)$. The location of the glucose unit was determined to be at C-4 by analysis of the HMBC data showing a correlation from $\mathrm{H}-1^{\prime}$ to $\mathrm{C}-4$. The coupling constant $(7.7 \mathrm{~Hz})$ of the anomeric proton of glucose suggested that it was the $\beta$-form. Acid hydrolysis of 15 yielded 3-hydroxy-1-(4-hydroxy-3,5-dimethoxyphenyl)-1-propanone (15a), whose ${ }^{1} \mathrm{H}$ NMR spectral data were in good agreement with the values reported previously [22], and D-glucopyranose was identified through co-TLC and the specific rotation value $\left\{[\alpha]_{\mathrm{D}}{ }^{25}+86.0(c 0.03, \mathrm{MeOH})\right\}$. Accordingly, the structure of compound 15 was identified as 2,6-dimethoxy-4-(1-oxo-3hydroxypropyl)phenyl $\beta$-D-glucopyranoside and named aleuriteoside A.

Compound 16 was isolated as a colorless gum and the molecular formula was determined to be $\mathrm{C}_{24} \mathrm{H}_{24} \mathrm{NO}_{14}$ from the $[\mathrm{M}+\mathrm{Na}]^{+}$ion in the positive ion HRESIMS. The ${ }^{1} \mathrm{H}$ NMR spectrum of 16 (Table 2) showed two 1,3,4,5-tetrasubstituted aromatic rings $\left[\delta_{\mathrm{H}} 7.10\left(\mathrm{~s}, 2 \mathrm{H}, \mathrm{H}-2^{\prime \prime}\right.\right.$ and $\left.\mathrm{H}-6^{\prime \prime}\right)$, and $7.11(\mathrm{~s}, 2 \mathrm{H}$, $\mathrm{H}-2^{\prime \prime \prime}$ and $\left.\left.\mathrm{H}-6^{\prime \prime \prime}\right)\right]$, a terminal olefinic methylene $\left[\delta_{\mathrm{H}} 5.97\right.$ (br s, $1 \mathrm{H}, \mathrm{H}-3 \mathrm{a}$ ), and 5.95 (br s, 1H, H-3b)], two oxygenated methylenes $\left[\delta_{\mathrm{H}} 4.34(\mathrm{dt}, J=13.7,1.5 \mathrm{~Hz}, 1 \mathrm{H}, \mathrm{H}-4 \mathrm{a})\right.$ and $4.22(\mathrm{dt}$, $J=13.7,1.5 \mathrm{~Hz}, 1 \mathrm{H}, \mathrm{H}-4 \mathrm{~b}) ; 4.57$ (dd, $J=12.0,2.0 \mathrm{~Hz}, 1 \mathrm{H}$, H-6'a) and 4.46 (dd, $\left.\left.J=12.0,5.0 \mathrm{~Hz}, 1 \mathrm{H}, \mathrm{H}-6^{\prime} \mathrm{b}\right)\right]$, and an anomeric proton $\left[\delta_{\mathrm{H}} 4.70\left(\mathrm{~d}, J=8.0 \mathrm{~Hz}, 1 \mathrm{H}, \mathrm{H}-1^{\prime}\right)\right]$. The ${ }^{13} \mathrm{C}$ NMR spectrum of $\mathbf{1 6}$ (Table 2) revealed 24 carbons, including two galloyl moieties $\left[\delta_{\mathrm{C}} 168.4,167.7,146.7(\times 2), 146.6\right.$ $(\times 2), 140.1(\times 2), 121.4(\times 2), 110.6(\times 2)$, and $110.3(\times 2)]$, a glucose moiety $\left(\delta_{\mathrm{C}} 102.1,76.2,76.0,75.2,71.8\right.$, and 64.5$)$, and 2-(hydroxymethyl)acrylonitrile signals $\left(\delta_{C} 133.2,121.3,118.2\right.$, and 69.3). 1D NMR spectra of $\mathbf{1 6}$ were similar to those of taxilluside $\mathrm{C}$ [23], except for the presence of a 2-(hydroxymethyl)acrylonitrile moiety at C-1' instead of 1,1-dimethylallyl alcohol. Furthermore, the NMR signals of cyanoglucoside moiety of $\mathbf{1 6}$ were in good agreement with literature data reported from Codiaeum variegatum belonging to the same family [24]. The location of the glucose unit was determined to be at $\mathrm{C}-4$ based on the analysis of the HMBC data showing a correlation from $\mathrm{H}-1^{\prime}$ to $\mathrm{C}-4$ (Figure 2). The HMBC cross-peaks of $\mathrm{H}-2^{\prime} / \mathrm{C}-7^{\prime \prime}$ and $\mathrm{H}-6^{\prime} / \mathrm{C}-7^{\prime \prime \prime}$ also indicated the presence of two galloyl groups at C-2' and C-6' of the glucose unit, respectively (Figure 2). Alkaline hydrolysis of $\mathbf{1 6}$ yielded codiacyanogluco- side (16a) and gallic acid (16b). The identification of $\mathbf{1 6 a}$ and $16 \mathbf{b}$ was conducted by comparison of their ${ }^{1} \mathrm{H}$ NMR and MS data [24,25]. Consequently, the structure of $\mathbf{1 6}$ was determined to be codiacyano glucosyl-2',6'-O-digallate, named aleucyanoglucoside.

The other known compounds were identified as $7 R, 8 S$-dihydrodehydrodiconiferyl alcohol 4- $O$ - $\beta$-D-glucopyranoside (4) [26], icariside $\mathrm{E}_{4}(5)$ [17], isomassonianoside B (6) [27], sakuraresinol (7) [28], selaginellol $4^{\prime}-O-\beta$-D-glucopyranoside (8) [21], $7 R, 8 R-4,7,9,9^{\prime}$-tetrahydroxy-3,3'-dimethoxy-8-O-4' neolignan-7-O- $\beta$-D-glucopyranoside (9) [29], $7 R, 8 R-4,9,9^{\prime}-$ trihydroxy-3,3'-dimethoxy-8-O-4'-neolignan (10) [30], 7S,8S4,9,9'-trihydroxy-3,3'-dimethoxy-8-O-4'-neolignan (11) [30], $7 R, 8 S-4,7,9,9^{\prime}$-tetrahydroxy-3,3'-dimethoxy-8- $O-4^{\prime}$-neolignan7-O- $\beta$-D-glucopyranoside (12) [29], 7S,8R-4,7,9-trihydroxy3,3'-dimethoxy-8-O-4'-neolignan-9'-O- $\beta$-D-glucopyranoside (13) [31], buddlenol A (14) [32], aleuritin (17) [33], fraxinol (18) [34], and 5,6,7-trimethoxycoumarin (19) [34] based on the comparison of their spectroscopic data and specific rotation with the reported data.

Compounds 1-19 were tested for their effects on nitric oxide (NO) production levels in lipopolysaccharide (LPS)-stimulated murine microglial BV-2 cells to evaluate for antineuroinflammatory activities (Table 3). Compound $\mathbf{1 4}$ showed relative inhibitory effects on $\mathrm{NO}$ production with an $\mathrm{IC}_{50}$ value of $20.9 \mu \mathrm{M}$ which was stronger than the positive control (L-NMMA, $\mathrm{IC}_{50} 28.8 \mu \mathrm{M}$ ). Compounds 11, 17, and 19 also displayed moderate activity $\left(\mathrm{IC}_{50} 35.5-37.1 \mu \mathrm{M}\right)$, whereas compounds $2,4,10,12$, and 13 exhibited only weak effects ( $\left.\mathrm{IC}_{50} 42.1-55.0 \mu \mathrm{M}\right)$. Interestingly, compounds $\mathbf{2}$ and $\mathbf{5}$ have the same planar structures with only differing in the C-7 stereochemistry, but they showed quite different inhibition effects on NO production $\left(\mathrm{IC}_{50} 55.0 \mu \mathrm{M}, \mathbf{2} ; \mathrm{IC}_{50}>500 \mu \mathrm{M}, \mathbf{5}\right)$. The MTT cell viability test suggested that all the compounds had no cytotoxic effect on BV-2 cell survival at a concentration of $20 \mu \mathrm{M}$.

Compounds 1-19 were also tested for their neuroprotection activity by measuring the secretion of NGF from C6 cells into the medium (Table 4). Compounds 8 and $\mathbf{1 6}$ stimulated NGF release, exhibiting stimulation levels of $134.2 \pm 8.1 \%$ and $134.6 \pm 5.9 \%$, respectively. Although compounds $\mathbf{3}$ and $\mathbf{8}$ have similar structures without or with a methoxy group at C-5, respectively, only compound $\mathbf{8}$ showed a significant activity $(96.2 \pm 1.1 \%$ for 3$)$. The other compounds exhibited moderate or no NGF secretion effect.

The cytotoxicity of compounds $\mathbf{1} \mathbf{- 1 9}$ was also evaluated against four human cancer cell lines (A549, SK-OV-3, SK-MEL-2, and 


\begin{tabular}{|cccccc}
\hline \multicolumn{6}{l}{ Table 3: Effects of isolated compounds on NO production in LPS-activated BV-2 cells. } \\
\hline comp. & $I_{50}(\mu \mathrm{M})^{\mathrm{a}}$ & cell viability\% & comp. & IC $_{50}(\mu \mathrm{M})^{\mathrm{a}}$ & cell viability\% $^{\mathrm{b}}$ \\
\hline $\mathbf{1}$ & $>500$ & $87.5 \pm 5.1$ & $\mathbf{1 1}$ & 37.1 & $89.97 \pm 3.2$ \\
$\mathbf{2}$ & 55.0 & $90.3 \pm 3.1$ & $\mathbf{1 2}$ & 47.6 & $90.1 \pm 3.7$ \\
$\mathbf{3}$ & 109.8 & $93.1 \pm 3.5$ & $\mathbf{1 3}$ & 42.1 & $87.9 \pm 4.2$ \\
$\mathbf{4}$ & 48.6 & $86.9 \pm 6.5$ & $\mathbf{1 4}$ & 20.9 & $105.2 \pm 1.5$ \\
$\mathbf{5}$ & $>500$ & $111.9 \pm 4.3$ & $\mathbf{1 5}$ & 93.7 & $93.3 \pm 7.4$ \\
$\mathbf{6}$ & 74.6 & $86.2 \pm 6.2$ & $\mathbf{1 6}$ & $>500$ & $95.8 \pm 4.2$ \\
$\mathbf{7}$ & 278.8 & $90.2 \pm 4.1$ & $\mathbf{1 7}$ & 35.5 & $101.8 \pm 4.2$ \\
$\mathbf{8}$ & 126.6 & $87.9 \pm 5.1$ & $\mathbf{1 8}$ & 117.0 & $96.6 \pm 4.4$ \\
$\mathbf{9}$ & 321.7 & $87.9 \pm 7.6$ & $\mathbf{1 9}$ & 36.7 & $99.7 \pm 2.9$ \\
$\mathbf{1 0}$ & 42.9 & $86.3 \pm 4.4$ & L-NMMA $^{\mathrm{c}}$ & 28.8 & $99.9 \pm 3.6$ \\
\hline
\end{tabular}

aThe $\mathrm{IC}_{50}$ value of each compound was defined as the concentration $(\mu \mathrm{M})$ that caused $50 \%$ inhibition of NO production in LPS-activated BV-2 cells. bThe cell viability after treatment with $20 \mu \mathrm{M}$ of each compound was measured using the MTT assay and is expressed as a percentage (\%). Results are the means of three independent experiments, and data are expressed as the means \pm SD. 'Positive control substance.

Table 4: Effects of isolated compounds on NGF secretion in C6 cells.

\begin{tabular}{|c|c|c|c|c|c|}
\hline comp. & NGF secretion ${ }^{a}(\%)$ & cell viability ${ }^{b}(\%)$ & comp. & NGF secretion ${ }^{a}(\%)$ & cell viability ${ }^{b}(\%)$ \\
\hline 1 & $117.4 \pm 2.8$ & $92.7 \pm 1.3$ & 11 & $102.1 \pm 5.4$ & $92.3 \pm 0.3$ \\
\hline 2 & $101.3 \pm 7.6$ & $90.5 \pm 0.1$ & 12 & $110.3 \pm 0.8$ & $94.0 \pm 1.9$ \\
\hline 3 & $96.2 \pm 1.1$ & $91.0 \pm 0.8$ & 13 & $104.5 \pm 3.2$ & $92.9 \pm 0.2$ \\
\hline 4 & $99.1 \pm 1.0$ & $93.9 \pm 1.1$ & 14 & $12.0 \pm 0.4$ & $99.6 \pm 3.1$ \\
\hline 5 & $102.5 \pm 8.0$ & $91.1 \pm 2.0$ & 15 & $111.3 \pm 7.6$ & $98.0 \pm 4.1$ \\
\hline 6 & $113.9 \pm 0.9$ & $93.0 \pm 0.5$ & 16 & $134.6 \pm 5.9$ & $88.8 \pm 3.9$ \\
\hline 7 & $101.2 \pm 5.8$ & $97.9 \pm 0.3$ & 17 & $102.1 \pm 2.5$ & $98.7 \pm 2.7$ \\
\hline 8 & $134.2 \pm 8.1$ & $94.5 \pm 3.9$ & 18 & $99.2 \pm 2.7$ & $97.9 \pm 4.3$ \\
\hline 9 & $121.0 \pm 0.6$ & $94.4 \pm 1.8$ & 19 & $104.1 \pm 4.6$ & $98.7 \pm 3.7$ \\
\hline 10 & $109.0 \pm 5.3$ & $92.9 \pm 4.1$ & 6-shogaolc & $143.9 \pm 12.5$ & $95.6 \pm 1.8$ \\
\hline
\end{tabular}

aC6 cells were treated with $20 \mu \mathrm{M}$ of each test compound. After $24 \mathrm{~h}$, the content of NGF secreted in the C6-conditioned medium was measured by ELISA. The level of secreted NGF is expressed as the percentage of the untreated control (set as $100 \%$ ). ${ }^{b}$ Cell viability after treatment with $20 \mu \mathrm{M}$ of each compound was determined by an MTT assay and is expressed as a percentage (\%). Results are the means of three independent experiments, and the data are expressed as means \pm SD. CPositive control substance.

HCT-15) through an SRB assay. All the tested compounds showed no activity for the cell lines $\left(\mathrm{IC}_{50}>10 \mu \mathrm{M}\right)$.

\section{Conclusion}

Isolation of phytochemical constituents from the twigs of A. fordii led to the discovery of three new neolignan glycosides 1-3, a new phenolic glycoside $\mathbf{1 5}$, and a new cyanoglycoside $\mathbf{1 6}$ along with 14 known compounds 4-14 and 17-19. The structural characterization of the new compounds was conducted based on the analysis of their spectroscopic and spectrometric data, and chemical methods. All isolated compounds were tested for their antineuroinflammatory and neuroprotective activities. Compound $\mathbf{1 4}$ showed inhibition effects on NO production and the stereoisomers $\mathbf{2}$ and $\mathbf{5}$ demonstrated the difference in activity according to the configuration. Compounds $\mathbf{8}$ and $\mathbf{1 6}$ exhibited neuroprotection effects. Thus, this study indicates that the active phenolic compounds from A. fordii would be potential candidates for drug discovery associated with antineurodegenerative diseases.

\section{Experimental}

General experimental procedures. Optical rotations were measured on a JASCO P-2000 polarimeter. IR spectra were acquired with a JASCO FT/IR-4600 spectrometer. UV spectra were obtained on a Shimadzu UV-1601 UV-visible spectrophotometer. NMR spectra were recorded on a Bruker AVANCE III $700 \mathrm{NMR}$ spectrometer operating at $700 \mathrm{MHz}\left({ }^{1} \mathrm{H}\right)$ and $175 \mathrm{MHz}\left({ }^{13} \mathrm{C}\right)$ with chemical shifts given in ppm $(\delta)$ 
and a Varian UNITY INOVA 500 NMR spectrometer (Varian Palo Alto, CA, USA) operating at $500 \mathrm{MHz}\left({ }^{1} \mathrm{H}\right)$ and $125 \mathrm{MHz}\left({ }^{13} \mathrm{C}\right)$. HRESIMS spectra were obtained on a Waters SYNAPT G2 mass spectrometer and semipreparative HPLC was conducted using a Gilson 306 pump with a Shodex refractive index detector and a Phenomenex Luna $10 \mu \mathrm{m}$ column $(250 \times 10 \mathrm{~mm})$. Silica gel 60 (Merck, Darmstadt, 70-230 mesh, and 230-400 mesh) and RP-C 18 silica gel (Merck, 230-400 mesh) were used for column chromatography. Low-pressure liquid chromatography was performed over Merck LiChroprep Lobar-A Si gel 60 $(240 \times 10 \mathrm{~mm})$ with an FMI QSY-0 pump (ISCO). Merck precoated silica gel $\mathrm{F}_{254}$ plates and RP-18 $\mathrm{F}_{254 \text { s }}$ plates were used for TLC. Spots were detected on TLC under UV light or by heating after spraying the samples with anisaldehydesulfuric acid.

Plant material. Twigs of A. fordii were collected in Chungbuk Goesan, Korea in August 2012 and the plant was identified by Dr. Kang Ro Lee, Professor at Sungkyunkwan University. A voucher specimen (SKKU-NPL 1212) has been deposited in the herbarium of the School of Pharmacy, Sungkyunkwan University, Suwon, Republic of Korea.

Extraction and isolation. Twigs of $A$. fordii $(7.0 \mathrm{~kg})$ were extracted three times with $80 \%$ aqueous $\mathrm{MeOH}$ (each $10 \mathrm{~L} \times 1$ day) under reflux and filtered. The filtrate was evaporated under vacuum to obtain a crude $\mathrm{MeOH}$ extract (325 g), which was suspended in distilled water and successively partitioned with $n$-hexane, $\mathrm{CHCl}_{3}$, EtOAc, and $n$ - $\mathrm{BuOH}$, to yield $15 \mathrm{~g}, 15 \mathrm{~g}, 9 \mathrm{~g}$, and $23 \mathrm{~g}$ of each residue, respectively. The $\mathrm{CHCl}_{3}$-soluble layer (15.0 g) was separated by Sephadex LH-20 chromatography $(80 \%$ aq. $\mathrm{MeOH})$ to yield six fractions (C1-C6). Fraction C1 (2.0 g) was subjected to RP-C 18 silica gel chromatography, eluting with gradient solvent system $(30 \rightarrow 100 \%$ aq. $\mathrm{MeOH}$ ) to yield four subfractions (C2A-C2D). Fraction C2C (210 mg) was purified by semipreparative HPLC ( $2 \mathrm{~mL} / \mathrm{min}, 50 \%$ aq. $\mathrm{MeOH}$ ) to yield compounds $17(5 \mathrm{mg}$ ) and 19 (6 mg). Fraction C3 (5.2 g) was subjected to RP-C 18 silica gel chromatography, eluting with gradient solvent system $(30 \rightarrow 100 \%$ aq. $\mathrm{MeOH}$ ) to yield five subfractions (C3A-C3E). Fraction C3B (554 mg) was subjected to repeated RP-C 18 silica gel chromatography and further purified by semipreparative HPLC (50\% aq. MeOH) to yield compound 18 (8 mg). Fraction C3D (1.0 g) was subjected to repeated $\mathrm{RP}-\mathrm{C}_{18}$ silica gel chromatography and further purified by semipreparative HPLC ( $23 \%$ aq. $\mathrm{CH}_{3} \mathrm{CN}$ ) to yield compound $\mathbf{1 4}(5 \mathrm{mg})$. Fraction $\mathrm{C} 4$ $(0.5 \mathrm{~g})$ was subjected to $\mathrm{RP}-\mathrm{C}_{18}$ silica gel chromatography, eluting with gradient solvent system $(30 \rightarrow 100 \%$ aq. $\mathrm{MeOH})$ to yield six subfractions (C4A-C4F). Compounds 7 (4 mg), 10 $(4 \mathrm{mg})$, and $\mathbf{1 1}(4 \mathrm{mg})$ were obtained by purification of fraction
C4D (43 mg) and C4E (57 mg) using semipreparative HPLC ( $15 \%$ aq. $\left.\mathrm{CH}_{3} \mathrm{CN}\right)$.

The EtOAc-soluble layer (9.0 g) was separated on a silica gel column $\left(\mathrm{CHCl}_{3} / \mathrm{MeOH}\right.$ 15:1 $\rightarrow$ 1:1) to yield eight fractions (E1-E8). Fraction E7 (0.4 g) was subjected to RP-C $_{18}$ silica gel chromatography, eluting with gradient solvent system $(30 \rightarrow 100 \%$ aq. $\mathrm{MeOH})$ to yield nine subfractions (E7A-E7I). Fractions E7A (31 mg), E7B (98 mg), E7C (30 mg), and E7D (37 mg) were purified by semipreparative HPLC (15\% aq. $\mathrm{MeOH}$ and $25-30 \%$ aq. $\left.\mathrm{CH}_{3} \mathrm{CN}\right)$ to yield compounds $2(3 \mathrm{mg})$, $5(6 \mathrm{mg})$, and $15(3 \mathrm{mg})$. Fraction E8 (0.9 g) was subjected to RP-C ${ }_{18}$ silica gel chromatography, eluting with gradient solvent system $(30 \rightarrow 100 \%$ aq. $\mathrm{MeOH})$ to yield six subfractions (E8A-E8F). Compounds 4 (4 mg), 6 (3 mg), and 16 (4 mg) were obtained by purification of fractions E8B $(54 \mathrm{mg})$ and E8C (120 mg) using semipreparative HPLC (40\% aq. MeOH).

The $n$-BuOH-soluble layer (23.0 g) was chromatographed on a Diaion HP-20 column, eluting with an isocratic solvent system of $100 \% \mathrm{H}_{2} \mathrm{O}$ and $100 \% \mathrm{MeOH}$, yielding $\mathrm{H}_{2} \mathrm{O}$ and $\mathrm{MeOH}-$ soluble fractions. The $\mathrm{MeOH}$ fraction was subjected to separation on a silica gel column $\left(\mathrm{CHCl}_{3} / \mathrm{MeOH} / \mathrm{H}_{2} \mathrm{O}\right.$ 6:1:0.1 $\rightarrow$ 1:1:0.1) to afford five fractions (BM1-BM5). Fraction BM3 $(2.5 \mathrm{~g})$ was fractionated over an $\mathrm{RP}-\mathrm{C}_{18}$ silica gel column, eluting with gradient solvent system $(25 \rightarrow 100 \%$ aq. $\mathrm{MeOH})$ to give nine subfractions (BM3A-BM3I). Subfraction BM3E (61 mg) was purified by semipreparative HPLC (23\% aq. $\mathrm{CH}_{3} \mathrm{CN}$ ) to acquire compound $\mathbf{1 3}$ (3 mg). Compounds $\mathbf{3}$ (8 mg) and $8(8 \mathrm{mg})$ were isolated upon purification of subfraction BM3G (52 mg) by semipreparative HPLC (17\% aq. $\left.\mathrm{CH}_{3} \mathrm{CN}\right)$. Fraction BM4 (1.0 g) was subjected to passage over an $\mathrm{RP}_{-} \mathrm{C}_{18}$ silica gel column, eluting with gradient solvent system $(15 \rightarrow 100 \%$ aq. $\mathrm{MeOH})$ to acquire 17 subfractions (BM4A-BM4Q). Compounds 1 (5 mg) and 12 (9 mg) were obtained by purification of fraction BM4M $(65 \mathrm{mg})$ using semipreparative $\mathrm{HPLC}\left(15 \%\right.$ aq. $\left.\mathrm{CH}_{3} \mathrm{CN}\right)$. Fraction BM4N (58 mg) was purified by semipreparative $\mathrm{HPLC}\left(30 \%\right.$ aq. $\left.\mathrm{CH}_{3} \mathrm{CN}\right)$ to yield compound 9 (10 mg).

Aleuritiside A (1). Colorless gum; $[\alpha]_{\mathrm{D}}{ }^{25}-12.1$ (c 0.05 , $\mathrm{MeOH})$; IR (KBr) $v_{\text {max }}: 3360,2943,2830,1448,1033 \mathrm{~cm}^{-1}$; UV (MeOH) $\lambda_{\max }, \mathrm{nm}(\log \varepsilon): 282$ (1.40), 228 (3.61); ECD $(\mathrm{MeOH}) \lambda_{\max }, \mathrm{nm}(\Delta \varepsilon): 292$ (5.3), 248 (3.3), 221 (-2.1); ${ }^{1} \mathrm{H}$ and ${ }^{13} \mathrm{C}$ NMR data, see Table 1 ; positive HRMS-FAB $(m / z):[\mathrm{M}+\mathrm{Na}]^{+}$calcd for $\mathrm{C}_{25} \mathrm{H}_{32} \mathrm{O}_{11} \mathrm{Na}, 531.1837$; found, 531.1844 .

Aleuritiside B (2). Colorless gum; $[\alpha]_{\mathrm{D}}{ }^{25}-15.4$ (c 0.05 , $\mathrm{MeOH})$; IR (KBr) $v_{\max }: 3355,2945,2832,1453,1033 \mathrm{~cm}^{-1}$; $\mathrm{UV}(\mathrm{MeOH}) \lambda_{\max }, \mathrm{nm}(\log \varepsilon): 283$ (1.31), 230 (3.53); ECD 
$(\mathrm{MeOH}) \lambda_{\max }, \mathrm{nm}(\Delta \varepsilon): 276(-3.3), 248(5.1), 229(-8.5) \mathrm{nm}$; ${ }^{1} \mathrm{H}$ and ${ }^{13} \mathrm{C}$ NMR data, see Table 1 ; positive HRMS-ESI $(\mathrm{m} / \mathrm{z})$ : $[\mathrm{M}+\mathrm{Na}]^{+}$calcd for $\mathrm{C}_{26} \mathrm{H}_{34} \mathrm{O}_{10} \mathrm{Na}, 529.2050$; found, 529.2050.

Aleuritiside C (3). Colorless gum; $[\alpha]_{\mathrm{D}}{ }^{25}-23.4$ (c 0.05 , $\mathrm{MeOH})$; IR (KBr) $v_{\max }: 3361,2946,2830,1462,1029 \mathrm{~cm}^{-1}$; $\mathrm{UV}(\mathrm{MeOH}) \lambda_{\max }, \mathrm{nm}(\log \varepsilon): 275$ (2.53); ECD (MeOH) $\lambda_{\max }$, $\mathrm{nm}(\Delta \varepsilon): 273(-8.1), 236(-8.3) ;{ }^{1} \mathrm{H}$ and ${ }^{13} \mathrm{C}$ NMR data, see Table 1; positive HRMS-ESI $(\mathrm{m} / \mathrm{z}):[\mathrm{M}+\mathrm{Na}]^{+}$calcd for $\mathrm{C}_{26} \mathrm{H}_{36} \mathrm{O}_{11} \mathrm{Na}$, 547.2155; found, 547.2155.

Aleuriteoside A (15). Colorless gum; $[\alpha]_{\mathrm{D}}{ }^{25}-13.7$ (c 0.08 , $\mathrm{MeOH})$; IR (KBr) $v_{\text {max }}: 3321,2975,1675,1601,1453$, $1065 \mathrm{~cm}^{-1}$; UV (MeOH) $\lambda_{\max }, \mathrm{nm}(\log \varepsilon): 280$ (2.31); ${ }^{1} \mathrm{H}$ and ${ }^{13} \mathrm{C}$ NMR data, see Table 2; positive HRMS-ESI $(m / z):[\mathrm{M}+\mathrm{Na}]^{+}$calcd for $\mathrm{C}_{17} \mathrm{H}_{24} \mathrm{O}_{10} \mathrm{Na}, 411.1267$; found, 411.1260.

Aleucyanoglucoside (16). Colorless gum; $[\alpha]_{\mathrm{D}}{ }^{25}-33.5$ ( $c$ 0.30, $\mathrm{MeOH})$; IR (KBr) $v_{\max }: 3535,3330,2832,2218,1453,1033$ $\mathrm{cm}^{-1}$; UV (MeOH) $\lambda_{\max }, \mathrm{nm}(\log \varepsilon): 283$ (1.31), 230 (3.53); ${ }^{1} \mathrm{H}$ and ${ }^{13} \mathrm{C}$ NMR data, see Table 2; positive HRMS-ESI $(\mathrm{m} / \mathrm{z})$ : $[\mathrm{M}+\mathrm{Na}]^{+}$calcd for $\mathrm{C}_{24} \mathrm{H}_{24} \mathrm{NO}_{14} \mathrm{Na}, 572.1016$; found, 572.1014 .

Acid hydrolysis and sugar analysis. In a manner similar as described in [35], compounds $\mathbf{1}-\mathbf{3}$ and $\mathbf{1 5}$ (each 1.0-2.0 mg) were refluxed with $1 \mathrm{~mL}$ of $1 \mathrm{~N} \mathrm{HCl}$ for $1 \mathrm{~h}$ at $90{ }^{\circ} \mathrm{C}$. The hydrolysate was extracted with EtOAc and the aqueous layer was neutralized by passing it through an Amberlite IRA67 column to give the sugar. The sugar obtained from the hydrolysis was dissolved in anhydrous pyridine $(0.5 \mathrm{~mL})$ followed by adding of L-cysteine methyl ester hydrochloride (2.0 mg, Sigma-Aldrich, St. Louis, MO, USA). The mixture was stirred at $60{ }^{\circ} \mathrm{C}$ for $1.5 \mathrm{~h}$ and trimethylsilylated with 1-trimethylsilylimidazole $(0.1 \mathrm{~mL}$, Sigma-Aldrich, St. Louis, MO, USA) for $2 \mathrm{~h}$. The mixture was partitioned between $n$-hexane and $\mathrm{H}_{2} \mathrm{O}(1.0 \mathrm{~mL}$ each), and the organic layer $(1.0 \mu \mathrm{L})$ was analyzed by GC-MS. The identification of D-glucose and L-rhamnose was carried out by coinjection of the hydrolysate with standard silylated samples, giving a single peak at 9.730 and 9.712 min, respectively. Authentic samples (Sigma-Aldrich, St. Louis, MO, USA) that were treated in the same way showed a single peak at 9.730 and $9.708 \mathrm{~min}$, respectively.

Alkaline hydrolysis of 16. In a manner similar as described in [36], compound $16(1.0 \mathrm{mg})$ was hydrolyzed with $0.1 \mathrm{~N} \mathrm{KOH}$ $(1 \mathrm{~mL})$ at room temperature for $4 \mathrm{~h}$. The reaction mixture was subsequently passed through an ion exchange column (Dowex ${ }^{\circledR}$ 50WX8 hydrogen form, Sigma-Aldrich, St. Louis, MO, USA) using deionized water to remove $\mathrm{KOH}$. A portion of the reaction product was partitioned between EtOAc/ $\mathrm{H}_{2} \mathrm{O}$ (each $1.0 \mathrm{~mL}$ ) and the aglycone 16a was acquired from the EtOAcsoluble phase.

Measurement of nitric oxide production and cell viability. In a manner similar as described in [37], BV2 cells were used to test the inhibitory effect of the isolated compounds on LPSstimulated NO production $[38,39]$. The BV2 cells seeded on a 96-well plate $\left(4 \times 10^{4}\right.$ cells/well $)$ were treated with and without various concentrations of the test compounds. The treated cells were stimulated with LPS (100 ng/mL) and incubated for $24 \mathrm{~h}$. The level of nitrite $\left(\mathrm{NO}_{2}\right.$, a soluble oxidation product of $\left.\mathrm{NO}\right)$ in the culture medium was measured using the Griess reagent $(0.1 \% \mathrm{~N}$-1-naphthylethylenediamine dihydrochloride and $1 \%$ sulfanilamide in $5 \%$ phosphoric acid). The supernatant $(50 \mu \mathrm{L})$ in each well was harvested and mixed with an equal volume of Griess reagent. After $10 \mathrm{~min}$, the absorbance was measured at $570 \mathrm{~nm}$ with a microplate reader (Emax, Molecular Devices, Sunnyvale, CA, USA). Graded sodium nitrite solution was used as a standard to gauge $\mathrm{NO}_{2}$ concentration. Cell viability was assessed by the MTT assay.

Measurement of NGF secretion and cell viability assays. C6 glioma cells (Korean Cell Line Bank, Seoul, Republic of Korea) were used to measure the release of nerve growth factor (NGF) into the culture medium. The C6 cells were seeded onto 24-well plates at a density of $1 \times 10^{5}$ cells/well. After $24 \mathrm{~h}$, the cells were treated with serum-free DMEM and incubated with different concentrations of the test compounds for an additional $24 \mathrm{~h}$. The NGF levels were evaluated in the medium supernatant using an ELISA development kit. Cell viability was measured using the MTT assay and the results were expressed as a percentage of the control group (untreated cells).

Cytotoxicity assessment. The SRB assay was performed to evaluate cytotoxicity of all the isolated compounds against four cultured human cancer cell lines. The cell lines (National Cancer Institute, Bethesda, MD, USA) were used A549 (nonsmall cell lung adenocarcinoma), SK-OV-3 (ovarian malignant ascites), SK-MEL-2 (skin melanoma), and HCT-15 (colon adenocarcinoma). Each cell line was inoculated over standard 96-well flat-bottom microplates and incubated for $24 \mathrm{~h}$ at $37{ }^{\circ} \mathrm{C}$ in condition of a humidified atmosphere of $5 \% \mathrm{CO}_{2}$. The attached cells were incubated with various concentrations of the test compounds and the cells were cultured for $48 \mathrm{~h}$. Then, the culture medium was removed from each well and the cells were fixed with $10 \%$ cold trichloroacetic acid at $4{ }^{\circ} \mathrm{C}$ for $1 \mathrm{~h}$. After the supernatant was discarded and the plates were washed with tap water, the cells were stained with $0.4 \%$ SRB solution and incubated for $30 \mathrm{~min}$ at room temperature. These cells were 
washed to remove the unbound dye and subsequently solubilized with $10 \mathrm{mM}$ unbuffered Tris base solution ( $\mathrm{pH} 10.5)$. The absorbance was measured spectrophotometrically at $520 \mathrm{~nm}$ with a microtiter plate reader. Etoposide (Sigma Chemical Co., $\geq 98 \%$ ) was used as a positive control.

\section{Supporting Information}

\section{Supporting Information File 1}

Copies of NMR spectra including 1D and 2D NMR and

HRMS data of compounds 1-3, 15, and 16 and ECD

spectra of compounds $\mathbf{1}-\mathbf{3}$.

[https://www.beilstein-journals.org/bjoc/content/

supplementary/1860-5397-17-151-S1.pdf]

\section{Acknowledgements}

We are thankful to the Korea Basic Science Institute (KBSI) for the measurements on the NMR and mass spectra.

\section{Funding}

This research was supported by the Basic Science Research Program through the National Research Foundation of Korea (NRF), funded by the Ministry of Education, Science and Technology (2016R1A2B2008380).

\section{ORCID ${ }^{\circledR}$ iDs}

Kyoung Jin Park - https://orcid.org/0000-0001-8786-1644

Kang Ro Lee - https://orcid.org/0000-0002-3725-5192

\section{References}

1. Schönemann, A.; Edwards, H. G. M. Anal. Bioanal. Chem. 2011, 400 1173-1180. doi:10.1007/s00216-011-4855-0

2. Pencreac'h, G.; Graille, J.; Pina, M.; Verger, R. Anal. Biochem. 2002, 303, 17-24. doi:10.1006/abio.2001.5427

3. Ito, Y.; Yanase, S.; Tokuda, H.; Kishishita, M.; Ohigashi, H.; Hirota, M.; Koshimizu, K. Cancer Lett. 1983, 18, 87-95. doi:10.1016/0304-3835(83)90121-0

4. Okuda, T.; Yoshida, T.; Toh, N. Phytochemistry 1975, 14, 2513-2514. doi:10.1016/0031-9422(75)80383-9

5. Fozdar, B. I.; Khan, S. A.; Shamsuddin, T.; Shamsuddin, K. M.; Kintzinger, J. Phytochemistry 1989, 28, 2459-2461. doi:10.1016/s0031-9422(00)98005-1

6. Taniguchi, S.; Uechi, K.; Kato, R.; Ito, H.; Hatano, T.; Yazaki, K.; Yoshida, T. Planta Med. 2002, 68, 1145-1146. doi:10.1055/s-2002-36348

7. Lee, Y.-C.; Nobles, W. L. J. Am. Pharm. Assoc., Sci. Ed. 1959, 48, 162-165. doi:10.1002/jps.3030480308

8. Matsuda, S.; Nakao, Y.; Ohigashi, H.; Koshimizu, K.; Ito, Y. Int. J. Cancer 1986, 38, 859-865. doi:10.1002/ijc.2910380613
9. Matsumoto, T.; Nakamura, S.; Nakashima, S.; Ohta, T.; Ogawa, K.; Fukaya, M.; Tsukioka, J.; Hasei, T.; Watanabe, T.; Matsuda, H. Phytochemistry 2017, 137, 101-108. doi:10.1016/j.phytochem.2017.02.007

10. Kim, C. S.; Subedi, L.; Kim, S. Y.; Choi, S. U.; Kim, K. H.; Lee, K. R. J. Nat. Prod. 2015, 78, 1174-1178. doi:10.1021/acs.jnatprod.5b00090

11. Suh, W. S.; Kim, K. H.; Kim, H. K.; Choi, S. U.; Lee, K. R. Helv. Chim. Acta 2015, 98, 1087-1094. doi:10.1002/hlca.201500002

12. Takeda, Y.; Mima, C.; Masuda, T.; Hirata, E.; Takushi, A.; Otsuka, H. Phytochemistry 1998, 49, 2137-2139. doi:10.1016/s0031-9422(98)00362-8

13. Kim, T. H.; Ito, H.; Hayashi, K.; Hasegawa, T.; Machiguchi, T.; Yoshida, T. Chem. Pharm. Bull. 2005, 53, 641-644. doi:10.1248/cpb.53.641

14. Kim, C. S.; Subedi, L.; Park, K. J.; Kim, S. Y.; Choi, S. U.; Kim, K. H.; Lee, K. R. Fitoterapia 2015, 106, 147-152. doi:10.1016/j.fitote.2015.08.013

15. Hara, S.; Okabe, H.; Mihashi, K. Chem. Pharm. Bull. 1987, 35, 501-506. doi:10.1248/cpb.35.501

16. García-Muñoz, S.; Álvarez-Corral, M.; Jiménez-González, L.; López-Sánchez, C.; Rosales, A.; Muñoz-Dorado, M.; Rodríguez-García, I. Tetrahedron 2006, 62, 12182-12190. doi:10.1016/j.tet.2006.10.018

17. Nakanishi, T.; lida, N.; Inatomi, Y.; Murata, H.; Inada, A.; Murata, J.; Lang, F. A.; linuma, M.; Tanaka, T. Phytochemistry 2004, 65, 207-213. doi:10.1016/j.phytochem.2003.10.025

18. Tan, R. X.; Jakupovic, J.; Jia, Z. J. Planta Med. 1990, 56, 475-477. doi:10.1055/s-2006-961015

19. Dong, L.-P.; Ni, W.; Dong, J.-Y.; Li, J.-Z.; Chen, C.-X.; Liu, H.-Y. Molecules 2006, 11, 1009-1014. doi:10.3390/11121009

20. Miyase, T.; Ueno, A.; Takizawa, N.; Kobayashi, H.; Oguchi, H. Chem. Pharm. Bull. 1988, 36, 2475-2484. doi:10.1248/cpb.36.2475

21. Zhuo, J.-X.; Wang, Y.-H.; Su, X.-L.; Mei, R.-Q.; Yang, J.; Kong, Y.; Long, C.-L. Nat. Prod. Bioprospect. 2016, 6, 161-166. doi:10.1007/s13659-016-0095-5

22. Lee, T.-H.; Kuo, Y.-C.; Wang, G.-J.; Kuo, Y.-H.; Chang, C.-I.; Lu, C.-K.; Lee, C.-K. J. Nat. Prod. 2002, 65, 1497-1500. doi:10.1021/np020154n

23. Ding, B.; Dai, Y.; Hou, Y.-L.; Wu, X.-M.; Chen, X.; Yao, X.-S. Fitoterapia 2013, 86, 1-5. doi:10.1016/j.fitote.2013.01.017

24. Forero, J. E.; Avila, L.; Taborda, N.; Tabares, P.; López, A.; Torres, F.; Quiñones, W.; Bucio, M. A.; Mora-Pérez, Y.; Rugeles, M. T.; Joseph-Nathan, P.; Echeverri, F. Phytochemistry 2008, 69, 2815-2819. doi:10.1016/j.phytochem.2008.09.003

25. Gottlieb, H. E.; Kumar, S.; Sahai, M.; Ray, A. B. Phytochemistry 1991, 30, 2435-2438. doi:10.1016/0031-9422(91)83676-c

26. Matsuda, N.; Sato, H.; Yaoita, Y.; Kikuchi, M. Chem. Pharm. Bull. 1996, 44, 1122-1123. doi:10.1248/cpb.44.1122

27. He, W. J.; Fu, Z. H.; Han, H. J.; Yan, H.; Zeng, G. Z.; Ji, C. J.; Chu, H. B.; Zhang, Y. M.; Tan, N. H. Z. Naturforsch., B: J. Chem. Sci. 2011, 66, 733-739. doi:10.1515/znb-2011-0715

28. Morikawa, T.; Tao, J.; Ueda, K.; Matsuda, H.; Yoshikawa, M. Chem. Pharm. Bull. 2003, 51, 62-67. doi:10.1248/cpb.51.62

29. Cai, W.-H.; Matsunami, K.; Otsuka, H.; Shinzato, T.; Takeda, Y. J. Nat. Med. 2009, 63, 408-414. doi:10.1007/s11418-009-0344-6 30. Chin, Y.-W.; Chai, H.-B.; Keller, W. J.; Kinghorn, A. D. J. Agric. Food Chem. 2008, 56, 7759-7764. doi:10.1021/jf801792n

31. Matsuda, N.; Kikuchi, M. Chem. Pharm. Bull. 1996, 44, 1676-1679. doi:10.1248/cpb.44.1676 
32. Yang, X.-W.; Zhao, P.-J.; Ma, Y.-L.; Xiao, H.-T.; Zuo, Y.-Q.; He, H.-P.; Li, L.; Hao, X.-J. J. Nat. Prod. 2007, 70, 521-525.

doi:10.1021/np0603931

33. Xie, Y.-F.; Tao, Z.-M.; Wang, H.-B.; Qin, G.-W. Zhongguo Tianran Yaowu 2010, 8, 264-266. doi:10.3724/sp.j.1009.2010.00264

34. Tsukamoto, H.; Hisada, S.; Nishibe, S. Chem. Pharm. Bull. 1985, 33, 4069-4073. doi:10.1248/cpb.33.4069

35. Kim, C. S.; Subedi, L.; Kim, S. Y.; Choi, S. U.; Choi, S. Z.; Son, M. W.; Kim, K. H.; Lee, K. R. Phytochem. Lett. 2015, 14, 215-220. doi:10.1016/j.phytol.2015.10.014

36. Park, K. J.; Subedi, L.; Kim, S. Y.; Choi, S. U.; Lee, K. R. Bioorg. Chem. 2018, 77, 527-533. doi:10.1016/j.bioorg.2018.02.006

37. Kim, C. S.; Subedi, L.; Oh, J.; Kim, S. Y.; Choi, S. U.; Lee, K. R. J. Nat. Prod. 2017, 80, 1134-1140. doi:10.1021/acs.jnatprod.7b00111

38. Blasi, E.; Barluzzi, R.; Bocchini, V.; Mazzolla, R.; Bistoni, F. J. Neuroimmunol. 1990, 27, 229-237. doi:10.1016/0165-5728(90)90073-v

39. Choi, Y.; Lee, M. K.; Lim, S. Y.; Sung, S. H.; Kim, Y. C. Br. J. Pharmacol. 2009, 156, 933-940. doi:10.1111/j.1476-5381.2009.00022.x

\section{License and Terms}

This is an Open Access article under the terms of the Creative Commons Attribution License (https://creativecommons.org/licenses/by/4.0). Please note that the reuse, redistribution and reproduction in particular requires that the author(s) and source are credited and that individual graphics may be subject to special legal provisions.

The license is subject to the Beilstein Journal of Organic Chemistry terms and conditions:

(https://www.beilstein-journals.org/bjoc/terms)

The definitive version of this article is the electronic one which can be found at: https://doi.org/10.3762/bjoc.17.151 